\title{
PowerPoint Presentations Help Achieve Educational Objectives
}

\author{
Božena Džuganová and Anna Barnau \\ Jessenius Faculty of Medicine, Comenius University (SLOVAKIA)
}

\begin{abstract}
Oral communication skills are applied in everyday doctor-patient dialogue, communication between medical specialists as well as in formal presentation of a highly specialized theme at various professional meetings. PowerPoint presentations on various medical topics prepared and presented by students are a suitable method in achieving educational objectives set by education providers. The structure, content, and manner of presentations were evaluated by the teacher during presentations using an evaluation sheet, and students were then awarded grades. For many years it was believed by our teachers that students prefer to choose medical topics by themselves. During the last academic year an investigation was carried out to find out if this hypothesis was right. Two groups of fourteen first-year students were involved in the investigation. While students from the first group (G1) had a free choice of medical topics for their presentations, students from the second group (G2) could choose a topic from a list of preselected themes arising from their curriculum. At the end of the semester all participating students filled out questionnaires with scaling and open questions. The obtained data revealed that both presenters and audience students preferred topics related to the curriculum and achieved better grades in presentations.
\end{abstract}

Keywords: PowerPoint presentations, medical English, oral communication skills

\section{Introduction}

Many people believe that good presenters are born, not made. Communication in medicine is considered to be a series of learned skills rather than just a matter of personality. Personality is important but much of our ability to communicate has been learned and is not simply inherent in our genetic material $[1,2]$.

Although some people are more relaxed and comfortable speaking in front of others, everyone can learn the skills and techniques they need to increase their level of confidence and performance when presenting [3, 4].

We may have been born with a predisposition to communicate and interact with others but how well we develop these characteristics is strongly influenced by what we learn from our environment, experience and education [1]. The rare speakers who can truly hold an audience in the palm of their hand have usually learned their skills through having been mentored at some point and then by rehearsing their talks, often with colleagues [5].

Over the last 10 years, there can be observed an increasing pressure from professional medical bodies to improve the training and evaluation of doctors in communication. Similar pressure is placed by academic bodies on medical students. The result of such pressure is that communication skill teaching has become an independent and popular subject on all levels of medical education - undergraduate, residency, and continuing. Since the ability to communicate is one of the goals of teaching foreign languages for special purposes, to which teaching English for Medical Purposes (EMP) inevitably belongs, it is necessary to create activities that promote spontaneous speech, interaction and discussion [6, 7].

Oral communication skills cover a wide area, ranging from everyday medical (doctor-patient) interviews in various settings and circumstances, communication between medical specialists, to formal presentation of a highly specialized theme at various professional meetings. Good presentation and public speaking skills are crucial for many key ranks in today's medical world. A convenient time to train students in communication 
skills is the period of undergraduate education, which takes place both in hospitals and medical schools. PowerPoint presentations on various medical topics prepared and presented by students are a suitable method in achieving educational objectives set by the curriculum. The use of presentations in the EMP curriculum combines the teaching of organisational, pragmatic and communicative competences with professional knowledge $[8,9]$ specific for study programmes at Jessenius Faculty of Medicine in Martin, Slovakia.

For many years it was believed by our teachers that students prefer to choose medical topics for PP presentations by themselves because it provides them with more freedom, teaches them to work more independently, leads them to take on greater responsibility for their work and enables them to achieve better grades $[6,9]$. During the last academic year an investigation was carried out to find out if this hypothesis was right.

\section{Methodology}

\subsection{Teaching Methodology}

In PowerPoint (PP) presentation methodology two basic methodological approaches were applied: taskbased and skill-based ones $[1,10,11]$. Before work on a presentation started, students were given uniform and binding instructions concerning the structure, content, and manner of presentation [12].

After a student delivered a presentation of about 10 minutes in length and answered questions, the teacher and audience students judged the originality, creativity, and organization of content, design, knowledge of material, clarity of charts, graphs, and overall presentation. All the above mentioned points plus language knowledge (grammar accuracy, vocabulary appropriateness, speech fluency, and pronunciation), body language, use of visual aids and the timing of the presentation were evaluated according to specified Assessment Criteria for Oral Presentation into an elaborated PowerPoint Evaluation Form [9, 13], and students were awarded a fair grade.

\subsection{Research Methodology}

Last summer semester an investigation was carried out to find out if our hypothesis that a free choice of presentation themes is more effective in achieving educational objectives than themes chosen from a list of topics suggested by teachers. The preselected themes were closely connected to the curriculum and textbooks used. A cohort of twenty-eight English language students, divided into two groups of 14 students (labelled G1 and G2), participated in the research. They were first year students learning medical English who had passed the final leaving exam in English targeted at Level B2 of the Common European Framework of Reference for Languages [14]. All PP presentations were delivered during their regular classes. At the end of the semester all

participating students filled out a questionnaire (Q) with scaling and open questions [15], followed by a discussion and opinion exchange.

\subsubsection{Questionnaire}

The questionnaire differed in the last 2 points depending on the group of students. The five point Likert scale was used to evaluate all statements: $1=$ Strongly disagree, $2=$ Disagree, $3=$ No opinion, $4=$ Agree, $5=$ Strongly agree. The students were asked to respond to the following statements:

1. A PowerPoint presentation of a medical topic in English was new for me.

2. I have had experience with PP presentations from my previous school.

3. PP presentations are an interesting way of learning new medical themes.

4. I prefer to make a PP presentation instead of writing a current credit test.

5. Selection of material for a PP presentation took me a lot of time.

6. The allotted time of 10 minutes was sufficient for my presentation.

7. PP presentations of my colleagues helped me to understand better the new subject matter. 
8. Background knowledge helped me understand the contents of the presentation.

9. Q1 What has influenced the choice of the topic of your presentation?

10.Q2 Would you prefer a free choice of a topic for your PP presentation?

\subsubsection{List of Pre-Selected Medical Themes}

1. Alzheimer's \& Parkinson's disease

2. Sleep cycles

3. Melatonin and insomnia

4. The most common mental disorders

5. Bacterial and viral infections - meningitis

6. Infectious children diseases

7. Respiratory diseases - pneumonia, asthma

8. Cancer - stages and symptoms

9. Breast and lungs cancer

10. HIV and AIDS

11. The four principle examination techniques

12. Hospital admission - accidents and emergencies

13. Surgery - a general review

14. Anaesthetics

\subsubsection{Medical Themes Chosen by Students}

1. Canistherapy

2. Club foot

8. Hepatitis C

3. Epilepsy

9. Stem cells

4. Obesity

10. Progeria

5. Asthma

11. Smoking

6. Diabetes mellitus

12. Lyme disease

7. Down syndrome

13. Autism

14. Epidermolysis bullosa

\section{Results and Discussion}

The results of evaluation of statements 1-3 confirmed that PP presentations as a learning and teaching method were not new for our students. $92 \%$ of students had done similar presentations in various subjects at previous schools though it was new for them to present a medical topic. $85 \%$ of students consider PP presentations to be an interesting way of learning and teaching. To avoid misunderstandings in the manner of presentation, the students were given detailed instructions and had seen an illustrative sample of presentations $[16,17,18]$.

Statement 4: 25 students preferred to make a PP presentation instead of writing a current test.

Statement 5: Students of both groups had similar problems to find an appropriate source of medical material for their presentation. They drew ideas from the Internet, journals or medical textbooks.

Statement 6: 50\% students from G1 compared with only 10\% from G2 were not satisfied with the allotted time of 10 minutes and had problems with timing of their presentation. PowerPoint Evaluation Forms confirmed that presentations of G1 were 3-4 minutes longer than presentations of G2. G1 students had the tendency to provide too many facts. Presenting too many details may lead to cognitive overload and decreased data processing in listeners [19]. The presenters were the best informed "experts" in the chosen medical topic and sometimes overestimated the interest of the listeners in their topic.

Statements 7 and 8: A follow-up discussion revealed that G1 students often wanted to impress their colleagues with a medical theme unrelated to their current studies, e.g. Canistherapy, Progeria, Epidermolysis bullosa. Themes such as Obesity and Smoking were considered by audience students to be too simple, very general, and overused. While presentations of G2 were always connected with the subject matter, and formed part of the teaching unit, the audience students had no problem to follow them compared to G1 audience students that frequently lacked context and background knowledge. The G1 presenters were not always able to provide sufficient information, e.g. about ethical issues in acquiring stem cells from aborted embryos. 
Question Q1 revealed that selection of a theme was often influenced by schoolmates or roommates of a higher academic year (35\%), English language textbook (28\%), learning of other subjects (14\%), doctor parents (7\%), interest in the subject $(7 \%)$, or a random choice $(9 \%)$. From discussion we learnt that it had taken the students from one up to two weeks to choose the topic, find suitable material, and prepare the presentation.

Question Q2 revealed that G2 students saved time and stress connected with selection of the presentation theme. Except for one student, G2 students were satisfied with the topic chosen from preselected medical themes. Their satisfaction was reflected in the number of points they were awarded for their individual presentations. While the average number of points in G1 was 105, G2 achieved 113 points (120 points for a presentation were maximum), which meant better grades in G2 students. The achieved values given in percentage and points are listed in table 1. The graphic illustration of points indicates a more balanced performance of G2 compared to G1 students.

TABLE I Assessment of Presentations in Percentage and Points

\begin{tabular}{|c|r|r|r|}
\hline \multicolumn{2}{|c|}{ G 1 } & \multicolumn{1}{|c|}{ G 2 } \\
\hline percentage & points & percentage & points \\
\hline 81 & 97 & 99 & 119 \\
\hline 81 & 97 & 98 & 118 \\
\hline 91 & 109 & 93 & 112 \\
\hline 91 & 109 & 97 & 116 \\
\hline 81 & 97 & 96 & 115 \\
\hline 98 & 118 & 91 & 109 \\
\hline 76 & 91 & 98 & 118 \\
\hline 85 & 102 & 93 & 112 \\
\hline 98 & 118 & 89 & 107 \\
\hline 98 & 118 & 95 & 114 \\
\hline 95 & 114 & 98 & \\
\hline 91 & 109 & 91 & \\
\hline 68 & 82 & 91 & \\
\hline 90 & 108 & 91 & 118 \\
\hline Mean 87.42 & 105 & Mean 94.28 & \\
\hline
\end{tabular}

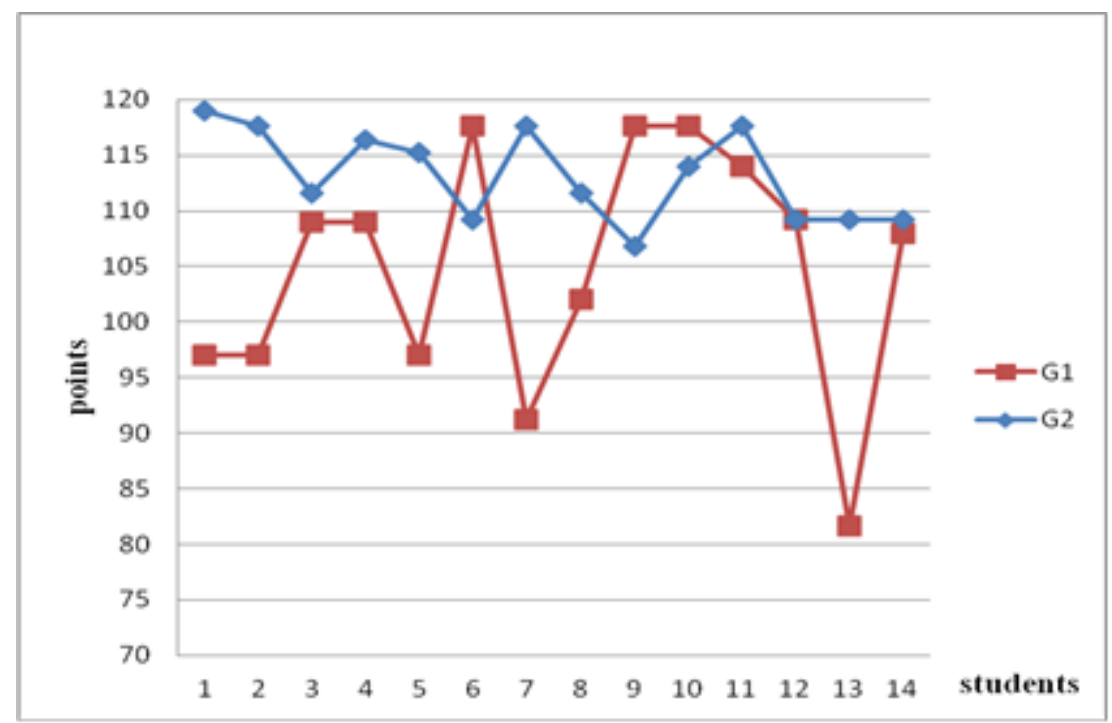

Fig. 1: Graphic visualisation of the presentation assessment

\section{Conclusion}

PP presentations of both groups G1 and G2 fulfilled the primary teaching goal, i.e. to teach students to deliver a specialized medical topic in front of an audience, to manage the anxiety and stress of speaking in public, to explain and describe complicated processes, to pay attention to nonverbal behaviour, i.e. to keep the posture and eye contact with the audience and avoid inappropriate movements or gestures, etc. Background knowledge 
of the subject matter achieved through an interdisciplinary learning approach and proper training of speaking skills helped the students to adopt the right expressions for oral presentation skills and enabled them to use appropriate words to explain complicated medical procedures, biological processes, and different disease courses in their presentations.

The students learnt to keep the prescribed structure and design, find balance between visual and oral sides of the presentation avoiding overuse of various sound and visual effects. They also gained insight into their own developing skills by discussing the strengths and weaknesses of presentations delivered by other students. Effectiveness of an oral presentation depends on the ability of the speaker to communicate with the audience. We are convinced that our future scientists must be empowered to bring science alive for any audience they might have to address - for the specialists they would encounter at a meeting, for the broad audience at their future job talks, and especially for the lay patient's audience in hospitals.

The assessment of PP presentations and the research statements and questions revealed that preselected topics not only saved time spent searching for a suitable theme and information but contributed to better presentation performance, which was measured by awarding points for individual parts of the PP presentation into the PowerPoint Evaluation Form according to the Assessment Criteria for Oral Presentation and led to better grades in G2 students. Our research hypothesis that students prefer to choose a medical topic for PP presentation by themselves was not confirmed; on the contrary, it was disproved.

\section{References}

[1] S. Kurzt, J. Silverman, J. Draper, Teaching and Learning Communication Skills in Medicine, $2^{\text {nd }}$ edition, Oxford: 2005, Radcliffe Publishing Ltd.

[2] J. C. Maher, International Medical Communication in English, 1990, Oxford University Press.

[3] J. Manktelow, How Good Are Your Presentation Skills? available: https://www.mindtools.com/pages/article/newCS_96.htm

[4] Communicating Science: Giving Talks, $2^{\text {nd }}$ edition, Burroughs Wellcome Fund, 2012, available: https://www.bwfund.org/sites/default/files/media/files/giving\%20talks.pdf

[5] A. E. Stuart, "Engaging the Audience: Developing Presentation Skills in Science Students," in Journal of Undergraduate Neuroscience Education, 2013 Fall, vol. 12(1), pp 4-10, available: https://www.ncbi.nlm.nih.gov/pmc/articles/PMC3852869/

[6] A. Barnau, B. Džuganová, "The Use of Presentations and Videos in Foreign Language Teaching," in Proc. Klúčové kompetencie pre celoživotné vzdelávanie, Prešov: Prešov University, 2016, pp. 13-19.

[7] M. Alley, The craft of scientific presentations: critical steps to succeed and critical steps to avoid, New York, 2003, Springer-Verlag Inc.

[8] R. Bergerová, "Studentské prezentace - jedna z aktivizačných forem cizojazyčné výuky," (Student presentations - one of the activating forms of foreign language teaching) in Cizí jazyky, 2007/2008, vol. 51, pp.133-135.

[9] B. Džuganová, "Presentations of Specialized Topics as a Way of Testing Communication Skills," in Testing language competence of tertiary students in LSP courses: collective monograph, Hradec Králové, 2014, TAH reklamní agentura, pp. 8-15.

[10] J. Willis, A Framework for Task-Based Learning, 1996, Longman.

[11] D. Willis, J. Willis, Doing Task-Based Teaching, Oxford, 2007, Oxford University Press.

[12] K. Ripley, How to Start an Oral Presentation, Demand Media, available: http://classroom.synonym.com/start-oral-presentation-4060.html

[13] E. Wolfenden, How to Evaluate an Oral Presentation, Demand Media, available: http://classroom.synonym.com/evaluate-oral-presentation-2661.html 
[14] Common European Framework of Reference for Languages: Learning, Teaching, Assessment. Language Policy Unit, Strasbourg, available:

https://www.coe.int/t/dg4/linguistic/Source/Framework_EN.pdf

[15] Z. Dornyei, Questionnaires in Second Language Research. Construction, Administration and Processing, London, 2003: Lawrence Erlbaum Associates

[16] T. Lynch, K. Anderson, Study Speaking. A Course in Spoken English for Academic Purposes, Cambridge: 1992, Cambridge University Press.

[17] A. Barnau, "Vizuálna podpora ako motivačný faktor vo výučbe angličtiny u študentov ošetrovatel'stva" (Visual Support as a Motivating factor of Teaching English in Nursing Students) in Cizí jazyky. (2014/2015), vol. 58, issue 5 pp. 25-37.

[18] A. Barnau, "Effective communication and visual aids in teaching ESP - a process and outcome evaluation," in Proc. Trendy v jazykovém vzděláváni v terciárni sfére v jazykových centrech na FF v ČR a SR 2 : testováni a měření jazykových kompetencí, 2015, available:

https://www.kal.upol.cz/fileadmin/kal/dokumenty/veda-vyzkum/trendy-v-jazykovem-vzdelavaniii/BARNAU_EDIT_FINAL.pdf

[19] J. Sweller, "Cognitive Load Theory, Learning Difficulty and Instructional Design," in Learning and Instruction, 1994, vol. 4, pp. 295-312.

https://doi.org/10.1016/0959-4752(94)90003-5 